\title{
Productive Potential of Yellow Passion Fruit Applying Mineral and Organic Fertilization with Worm Compost
}

\section{Potencial Produtivo do Maracujazeiro Amarelo sob Adubação Mineral e Orgânica com Vermicomposto}

\author{
Rodrigo dos Santos Rufino*a; José Antônio Maior Bono ${ }^{\text {b; Talles Edmundo de Assis }}{ }^{\mathrm{b}}$ \\ ${ }^{a}$ Anhanguera-Uniderp University. MS, Brazil. \\ ${ }^{\mathrm{b}}$ Anhanguera-Uniderp University, Agricultural Production and Management Graduate Program. MS, Brazil. \\ *E-mail: rodrigorufi@hotmail.com
}

\begin{abstract}
The yellow passion fruit (Passiflora edulis Sims) is a crop that requires large quantities of fertilizers, which mainly can be from organic or mineral source or combination of both. The objective of the present work was to evaluate the productivity and physical characteristics of fruits of yellow passion fruit in first and second crop cycle under mineral fertilization (NPK) associated with worm compost. The experiment was conducted on soil classified as Entisols Quartzipsamment in Campo Grande, MS, Brazil, with five treatments: 100\% mineral fertilization, $75 \%$ mineral fertilization with $25 \%$ worm compost, $50 \%$ mineral fertilization with $50 \%$ worm compost, $25 \%$ mineral fertilization with $75 \%$ worm compost and $100 \%$ worm compost. The treatments were randomly distributed with block design with four replications. Productivity, average number of fruits per plant, average weight of fruits, equatorial and longitudinal diameters of the fruit, relationship between diameters and Brix $^{\circ}$ of the fruits for two years were evaluated. The use exclusive of organic fertilizer, without the mineral fertilization significantly reduces the productivity of yellow Passiflora. The organic fertilizer promoted a complementary effect on fruits mass and diameter during the first crop cycle-
\end{abstract}

Keywords: Fruitful. Passionfruit. Fertilizer. Organic Fertilizer.

\section{Resumo}

O maracujazeiro amarelo (Passiflora edulis Sims) é uma cultura que necessita de altas quantidades de fertilizantes, que pode ser tanto de fonte mineral ou orgânica ou a combinação de ambas. O presente trabalho objetivou avaliar a produtividade e as caraterísticas fisicas dos frutos de maracujazeiro amarelo na primeira e segunda safra sob adubação mineral (NPK) em diferentes proporções complementada com adubação orgânica com vermicomposto. O experimento foi conduzido em solo classificado como Neossolo Quartzarênico Órtico em Campo Grande, MS, Brasil, com cinco tratamentos: $100 \%$ adubação mineral, $75 \%$ adubação mineral com $25 \%$ vermicomposto, $50 \%$ adubação mineral com $50 \%$ vermicomposto, $25 \%$ adubação mineral com $75 \%$ vermicomposto e $100 \%$ vermicomposto. Os tratamentos foram distribuidos em blocos ao acaso com quatro repetições. Foi avaliado a produtividade, número médio de frutos por planta, massa média dos frutos, diâmetros equatorial e longitudinal dos frutos, relação entre os diâmetros e o Brix ${ }^{\circ}$ por 2 anos. Somente o uso do adubo orgânico, sem o complemento da adubação mineral, reduz significativamente a produtividade do maracuzajeiro amarelo. A fertilização orgânica promoveu um efeito complementar em relação à adubação mineral sobre a massa e o diâmetro dos frutos na primeira safra.

Palavras-chaves: Frutífera. Maracujá. Adubação. Adubo Orgânico.

\section{Introduction}

The yellow passion fruit (Passiflora edulis Sims) is originally from tropical regions and represents a good option for farming due to the fact that it offers fast economic return, as well as the opportunity of a distributed revenue during almost all year (MELETTI, 2011).

Fertilization applied correctly significantly increases the productivity and quality of passion fruit. The amounts of $\mathrm{N}$, $\mathrm{P}$ and $\mathrm{K}$ recommended for the cultivation of passion fruit are very variable (FORTALEZA et al., 2005), but it is known that the passiflora is demanding in nutrients, which are supplied to plants by mineral and/or organic fertilization (DAVID et al., 2008). Nitrogen ( $\mathrm{N}$ ) is the most absorbed nutrient during the vegetative development of passion fruit (CAMPOS et al., 2007). Potassium (K) is absorbed during fruiting and accumulated in pulp and peel of fruits (VASCONCELLOS et al., 2001). Although phosphorus (P) is absorbed in small quantities by the passiflora, it is an important nutrient for energy storage and transfer processes (ALMEIDA, 2012).

An alternative method to improve efficiency of mineral fertilization of $\mathrm{N}$ and $\mathrm{K}$ is the association to organic matter. Among the sources of organic matter applied in agriculture, the use of humus produced by earthworms, also known as worm compost has been seen as an alternative of great sustainability, because it is a material rich in nutrients usable by plants. Sorrenti et al. (2008) reported that the use of vermicomposting could be used to supply nitrogen to tangerine plants, with a consequent reduction in mineral fertilization. Rodolfo Junior et al. (2009) observed in an experiment with bio fertilizers that the association with mineral fertilization with NPK led to increased growth of plants, more productive branches emissions, in addition to increased productivity.

The objective of this work was to evaluate the productivity 
and physical characteristics of yellow passion fruits in first and second cycle crop under mineral fertilization, associated with organic fertilization using worm compost in Entisols Quartzipsamment.

\section{Material and Methods}

The study was developed from August 2013 to September 2015 in Campo Grande, Mato Grosso do Sul, Brazil (20²6'15.52”S, 54³2'9.11'O, $620 \mathrm{~m}$ of altitude). The soil is classified as Typical Quartzipisamment Entisols and the climate region is located in the range of transition between the sub-type Cfa-mesothermal humid without drought and the sub-type Aw - tropical humid climate with rainy season in the summer and dry during winter according to Koppen classification. The cumulative rainfall in the experimental period was $1070 \mathrm{~mm}$ in the first and $1764 \mathrm{~mm}$ in the second crop cycle with an average maximum temperature of $29.2^{\circ} \mathrm{C}$ and average minimum temperature of at least $18.9^{\circ} \mathrm{C}$.

The area was prepared with a harrow, 4 months in advance to the transplantation. The soil was sampled at $0-20 \mathrm{~cm}$ and $20-$ $40 \mathrm{~cm}$ layers and the vermicomposts were analyzed according to Donagema et al. (2011) presented in Table 1.

Table 1 - Chemical and physical attributes of the soil in the experimental site

\begin{tabular}{|c|c|c|c|c|c|c|c|c|c|}
\hline \multirow{2}{*}{ Prof. (m) } & \multicolumn{2}{|c|}{$\mathrm{pH}$} & $\mathrm{P}$ & $\mathrm{K}$ & $\mathrm{Ca}$ & $\mathrm{Mg}$ & $\mathrm{Al}$ & \multirow{2}{*}{$\begin{array}{l}\begin{array}{c}\text { Organic } \\
\text { Matter }\end{array} \\
\mathrm{g} \mathrm{dm}^{-3}\end{array}$} & \multirow{2}{*}{$\begin{array}{l}\text { Clay } \\
\mathrm{g} \mathrm{kg}^{-1}\end{array}$} \\
\hline & water & $\begin{array}{c}\mathrm{CaCl} 2 \\
(0,01 \mathrm{M})\end{array}$ & \multicolumn{2}{|c|}{$\mathrm{mg} \mathrm{dm}^{-3}$} & \multicolumn{3}{|c|}{$\mathrm{cmol}_{+} \mathrm{dm}^{-3}$} & & \\
\hline 0.0 a 0.2 & 5.49 & 4.58 & 50 & 46 & 0.9 & 0.5 & 0.7 & 23.5 & 122 \\
\hline 0.2 a 0.4 & 5.37 & 4.47 & 47 & 20 & 0.6 & 0.7 & 0.9 & 17,2 & 131 \\
\hline
\end{tabular}

Source: Survey data.

The amount of lime applied in accordance with the recommendation by the saturation method, by bases was $1.46 \mathrm{t} \mathrm{ha}^{-1}$, type dolomite, spread without incorporation, throughout the experimental area, 90 days before the seedlings transplanting. The analysis of the worm compost showed the following results: $\mathrm{pH}=7, \mathrm{P}=260\left(\mathrm{mg} \mathrm{kg}^{-3}\right), \mathrm{K}=600(\mathrm{mg} \mathrm{kg}$ $\left.{ }^{3}\right) ; \mathrm{Ca}=25.0\left(\mathrm{cmol}_{+} \mathrm{kg}^{-3}\right) ; \mathrm{Mg}=22.0\left(\mathrm{cmol}_{+} \mathrm{kg}^{-3}\right)$ and organic matter $=129.55\left(\mathrm{~g} \mathrm{~kg}^{-3}\right)$. To determine the amount of mineral fertilizer (NPK) and organic fertilizer (worm compost), the interpretation of the soil analysis results was according to Alvarez et al. (1999).

For mineral fertilization recommendation the interpretation of soil analysis data was taken into consideration. The doses were established in accordance with the recommendation of Souza et al. (1999), $40 \mathrm{~g}$ of $\mathrm{P}_{2} \mathrm{O}_{5}$ per plant 60 days before transplantation, done at the opening of the hollows, $30 \mathrm{~g}$ of $\mathrm{N} 30$ days after transplantation, $40 \mathrm{~g}$ of $\mathrm{N}$ and $30 \mathrm{~g}$ of $\mathrm{K}_{2} \mathrm{O}$ per plant 90 days after transplantation and $60 \mathrm{~g}$ of $\mathrm{K}_{2} \mathrm{O}$ per plant 150 days after transplantation. The sources used for $\mathrm{N}, \mathrm{P}_{2} \mathrm{O}_{5}$ and $\mathrm{K}_{2} \mathrm{O}$ were, respectively, ammonium sulphate, triple superphosphate and potassium chloride. These doses corresponded to $100 \%$ of mineral fertilization. For organic fertilization, the dose established was $10 \mathrm{~L}$ of worm compost per plant based on total $\mathrm{K}$ content present in the vermicompost in relation to the recommended quantity of $\mathrm{K}$ for mineral fertilization, corresponding to $100 \%$ of the organic source, with two applications, $5 \mathrm{~L}$ in the opening of holes and $5 \mathrm{~L} 60$ days after transplantation.

At 60 days of transplantation, the holes opening and preparation were performed with dimensions of $0.5 \mathrm{~m}$ in diameter and $0.5 \mathrm{~m}$ depth. In the area of the grave $50 \mathrm{~g}$ of lime was added on the soil surface for all treatments.

The seedlings were obtained from hybrids seeds of
BRS giant yellow cultivar, sown in a commercial substrate, in cultivation bags with dimensions of $18 \times 21 \mathrm{~cm}$, at $1 \mathrm{~cm}$ depth, without fertilizer addition and transplanted 60 days after sowing.

Five treatments were evaluated in this experiment: Treatment $1-100 \%$ of mineral fertilization (100\%); Treatment $2-75 \%$ of mineral fertilization associated with $25 \%$ of organic fertilization with worm compost $(75 \% / 25 \%$ VC); Treatment 3- 50\% mineral fertilization associated with $50 \%$ of organic fertilization with worm compost $(50 \% / 50 \%$ VC); Treatment 4- $25 \%$ of mineral fertilization associated with $75 \%$ of organic fertilization with worm compost $(25 \% / 75 \% \mathrm{VC})$ and Treatment 5- without mineral fertilization.

The experimental design was in randomized blocks with four replications, counting each plot with 5 plants, being that the 3 central plants accounted for the useful plot size. The total area of the experiment was $1350 \mathrm{~m}^{2}$.

The transplantation was performed on December 18th 2013 under an irrigation located system type drip irrigation, with frequency and volume of controlled application with the support of tensiometers (installed at 20 and $30 \mathrm{~cm}$ depth) and the curve of moisture retention of the soil itself, considering a blade maximum to $11.75 \mathrm{~mm}$ and, especially during fruiting and flowering, a matric potential higher than $-20 \mathrm{kPa}$ according to Sousa et al. (2001).

The plant spacing used was $3 \times 5 \mathrm{~m}$ and the plants were carried out by vertical trellis system with straight wire of 1.8 $\mathrm{m}$ above the ground with the aid of a plastic support. In view of the presence of pollinator agent in the area, Mamangava (Xylocopa spp.) and carried handed pollination.

From the first week of May 2014 (first cycle) and April 2015 (second cycle), the fruits were collected and selected by peel color. After that, the evaluation of the following 
variables were performed: average number of fruits per plant, average weight of fruits, equatorial and longitudinal diameter of the fruits using a digital calliper and yield per plant that was extrapolated to hectare. The ratio of the diameters was considered as the product of the division between the values of the longitudinal diameter and the equatorial diameter. ${ }^{\circ}$ Brix was determined using the portable digital refractometer.

The data were analysed under analysis of variance and when significant up to $5 \%$ of probability, the Tukey test at $5 \%$ probability for the separation of the treatments was applied.

\section{Results and Discussion}

There was a significant effect of proportions of mineral fertilization complemented with worm compost for the variables: number of fruits per plant, productivity, the relationship between the length and diameter of the fruits and ${ }^{\circ}$ Brix in either the first or the second production cycle and for the variables mass of fruits, diameter of the fruit and length of fruits only in the second cycle (Table 2).

Table 2. Summary of the analysis of variance, for the variables number of fruits per plant (NFP), weight productivity of the fruit (WY), ${ }^{\circ}$ Brix, dry mass (DM), equatorial diameter (ED) and longitudinal diameter (LD) of the fruit and the relationship among the diameters (R-ED/LD) of the yellow passion fruit under mineral and organic (worm compost) fertilization.

\begin{tabular}{|c|c|c|c|c|c|c|c|}
\hline \multirow{3}{*}{ Variable } & \multicolumn{7}{|c|}{ Treatment } \\
\hline & \multicolumn{3}{|c|}{$1^{\text {st }}$ cycle } & \multicolumn{3}{|c|}{$2^{\text {nd }}$ cycle } & \multirow{2}{*}{ CV $(\%)$} \\
\hline & Mean Square & $\mathrm{F}$ & $\operatorname{Pr}>F$ & Mean Square & $\mathrm{F}$ & $\operatorname{Pr}>F$ & \\
\hline NFP & 794.19 & 8.59 & $0.0016 * *$ & 85.21 & 9.77 & $0.0004 * *$ & 12.73 \\
\hline WY & 34.84 & 8.55 & $0.0017 * *$ & 7.32 & 10.28 & $0.0003 * *$ & 14.81 \\
\hline${ }^{\circ}$ Brix & 12.54 & 3.56 & $0.0257^{*}$ & 17.53 & 5.79 & $0.0023 * *$ & 9.78 \\
\hline DM & $1,127.70$ & 1.03 & $0.0819 \mathrm{~ns}$ & $1,431.18$ & 3.67 & $0.0329 *$ & 10.53 \\
\hline LD & 117.11 & 4.65 & $0.0869 \mathrm{~ns}$ & 162.88 & 5.38 & $0.0117 *$ & 9.44 \\
\hline ED & 66.60 & 3.0 & $0.0624 \mathrm{~ns}$ & 83.35 & 4.82 & $0.0329 *$ & 8.77 \\
\hline R-ED/LD & 0.0029 & 10.43 & $0.0007 * *$ & 0.013 & 7.64 & $0.0045 * *$ & 3.27 \\
\hline
\end{tabular}

$\mathrm{ns}=$ non-significant, ${ }^{*}$ and $* *$ significant at $5 \%$ and $1 \%$, respectively. $\mathrm{CV}=$ coefficient de variance $\mathrm{F}=$ statistic $\mathrm{F}$ of analyser variance Pr=Probability Source: Survey data

In the two cycles, the number of fruits per plant increased linearly with the increase in the proportion of mineral fertilization (Figure 1).

Figure 1 - Means of the number of fruits per plant of yellow passion fruit under mineral and organic (worm compost) fertilization in Entisols Quartzipsamment

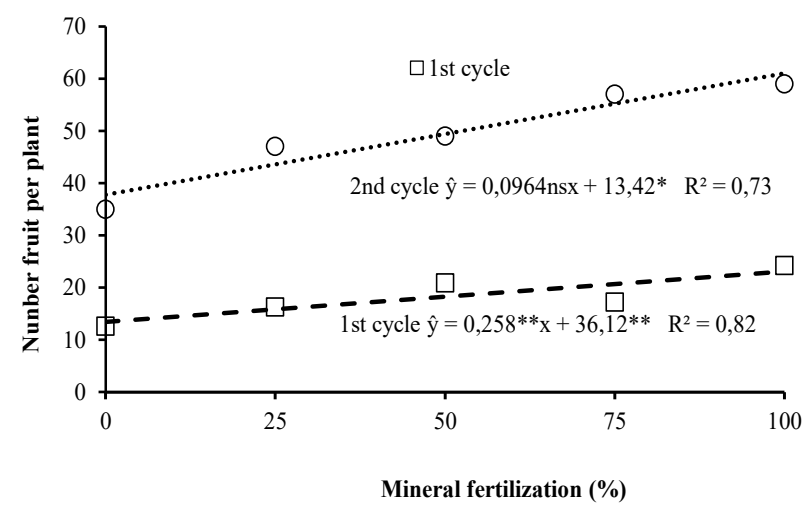

$\mathrm{ns}=$ non-significant, $*$ and $* *$ significant at $5 \%$ and $1 \%$, respectively Source: survey data

This is probably due to the increase in the quantity of $\mathrm{N}$, $\mathrm{P}$, and mainly $\mathrm{K}$ readily available to plants provided by the mineral fertilizer. The importance of $\mathrm{K}$ is associated to plant metabolism by collaborating with the fruits establishment and development. Araújo et al. (2005) found that the percentage of set of fruits was directly proportional to the increase in the concentration of $\mathrm{K}$ in nutrient solution. Probably, there was also the effect of $\mathrm{S}$, because according to Tiecher et al. (2013) cultures grown in soils with low organic matter and clay content, as sandy texture, may submit responses to the application of $\mathrm{S}$. In the first year of cultivation, by means of ammonium sulphate, the total of $77 \mathrm{~g}$ of surfur $(\mathrm{S})$ to the ratio $100 \%$, was applied to the soil, while in proportion to $0 \%$, just to compare, only $16.5 \mathrm{~g}$ of $\mathrm{S}$ originating from the worm compost complement, with the detail that it is an organic source, whose availability of nutrients for the plants depends on the mineralization process. Assuming the proportion $0 \%$, to each increase of $25 \%$ of the mineral fertilization, $15 \mathrm{~g}$ of $\mathrm{N}$ was applied to the soil. In the second year of cultivation, the total of $33 \mathrm{~g}$ of $\mathrm{S}$ to the ratio $100 \%$ was applied and while the proportion $0 \%$ has not received any application of $\mathrm{S}$, thus, to each increase of $25 \%$ of mineral fertilization, $8.25 \mathrm{~g}$ of $\mathrm{S}$ was applied to the soil.

The treatment with $100 \%$ mineral fertilization was 53\% and $63 \%$, respectively, in the 1 st and 2 nd cycle, higher relative treatment without mineral fertilization, indicating that only the vermicompost does not replace mineral fertilization (Figure 2). 
Figure 2 - Means of the productivity of fruit of yellow passion fruit under mineral and organic (worm compost) fertilization in Entisols Quartzipsamments

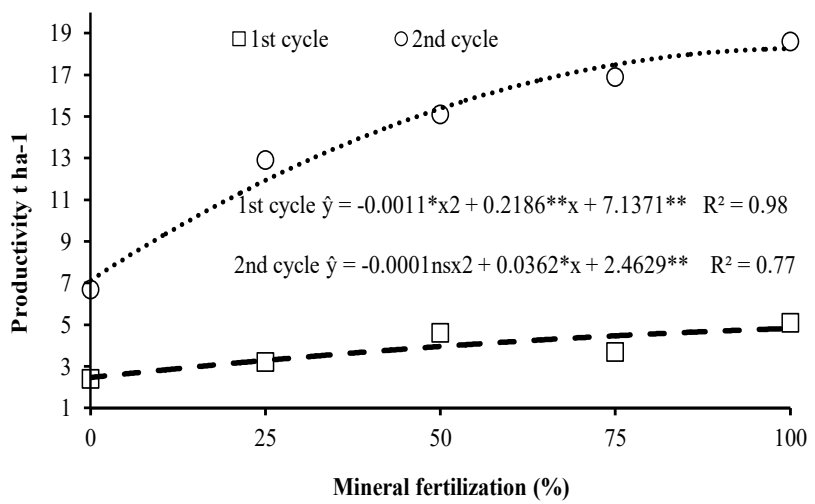

$\mathrm{ns}=$ non-significant, $*$ and $* *$ significant at $5 \%$ and $1 \%$, respectively

Source: survey data.

Working with passion yellow fruit, Pires et al. (2009) observed a productivity 21 and $25 \%$ higher with the use of mineral fertilization when compared with the organic fertilization and Pacheco et al. (2017) observed a productivity $29 \%$ higher.

These results show that, although the fertilization was complemented with worm compost, the passion fruit still depended on the mineral fertilizer to express its productivity. This fact can be attributed to some factors. First, the complementary dose of worm compost established based on the amount of $\mathrm{K}$ recommended for mineral fertilization, may have been low, including to provide significant quantities of organic matter to the soil and cause positive changes in its physical, chemical and biological attributes, which could positively influence the passion fruit productivity. Souza et al. (2016), in a study in soil with texture ranging from sandy to sandy loam, only obtained superior responses with the organic fertilization in relation to mineral fertilizer for corn productivity, with a dose 4 times higher than the recommended amount based on $\mathrm{N}$, which is equivalent to a dose of $30.45 \mathrm{~kg}$ of worm compost, double the dose established for this study. Associated with the low dosage, the supply of N, P and $\mathrm{K}$ may have been another limiting factor. The supplementary dose of worm compost established could provide to the soil $195 \mathrm{~g}$ of $\mathrm{N}, 84 \mathrm{~g}$ of $\mathrm{P}$ and $75 \mathrm{~g}$ of $\mathrm{K}$, which, however, were in the process of mineralization to be released to the plants. Freitas et al. (2012) observed rates of mineralization in the order of $46 \%$ of $\mathrm{N}$ and $77 \%$ of $\mathrm{P}$ after 210 days and rate of release of $71 \% \mathrm{~K}$ after 150 days for bovine manure. However, it is probable that the worm compost, because it is a stable material, present lower rates of mineralization. Finally, as Mueller et al. (2013) noted for the organic fertilization, there may have been a lack of synchronism between the availability of complementation nutrients with worm compost and the periods of higher nutrients accumulation by the passion fruit plant.

The productivity of $23.7 \mathrm{t}$ obtained with the ratio $100 \%$ was lower compared with the values obtained by Weber et al. (2016) of $51.4 \mathrm{t} \mathrm{ha}^{-1}$ using another cultivar and Vale et al. (2013) de $62 \mathrm{t} \mathrm{ha}^{-1}$ using the same cultivar. This fact was justified by the non-performing of artificial pollination and the lower plant density. Krause et al. (2012) found in a study developed with 7 cultivars of sour-passion fruit for 8 months, that the average productivity of the same was increased from $5.92 \mathrm{t} \mathrm{ha}^{-1}$ to $16.41 \mathrm{t} \mathrm{ha}^{-1}$ with the practice of artificial pollination. Weber et al. (2016) found that, with the greatest density at planting, with 3200 plants ha -1 , the productivity increased by $31 \%$, registering a value of $51.4 \mathrm{tha}^{-1}$

The increase in the proportion of mineral fertilization had no influence on the mass of the fruits in the first cycle, suggesting that the worm compost presented additional effect. Pires et al. (2009) and Rodolfo Júnior et al. (2009) working with the organic, mineral fertilization and with both in association, also found no differences (Figure 3).

Figure 3 - Means of the dry mass of fruits of the yellow passion fruit under mineral and organic (worm compost) fertilization in Entisols Quartzipsamments

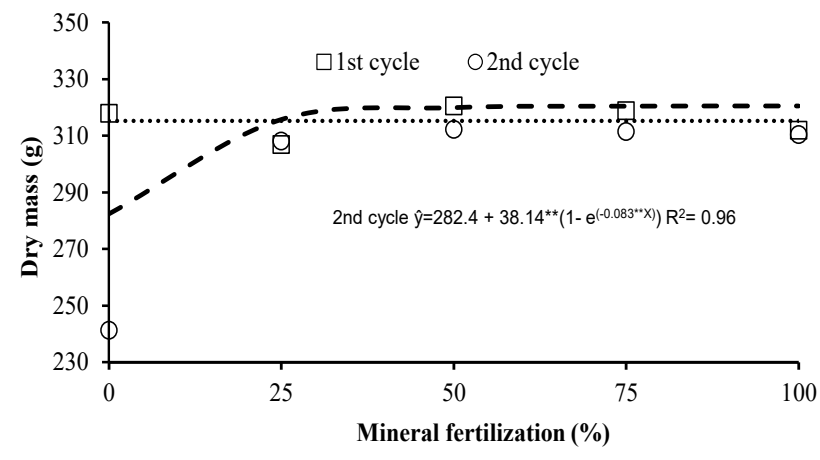

$\mathrm{ns}=$ non-significant, $*$ and $* *$ significant at $5 \%$ and $1 \%$, respectively Source: survey data.

In the second cycle, the mass of fruits increased exponentially until the estimated proportion of $35 \%$, because, probably, below this proportion the supply of nutrients, especially $\mathrm{N}$ and $\mathrm{K}$, with reported effects on the variable in question (AULAR et al., 2014), was short of the demand of plant of passion fruit to express the limit of mass gain of fruits, which may have occurred due to the supplementary nitrogen fertilization have been residual and not present effect. With the same cultivar, Aguiar et al. (2017) obtained fruits with mass of $325.7 \mathrm{~g}$ and Cavalcante et al. (2016) with a mass of $257 \mathrm{~g}$, interval that includes the values obtained in this study of $320 \mathrm{~g}$, for the first cycle, and $318.4 \mathrm{~g}$, for the second cycle.

The diameter and length of the fruit increased with the increase in the proportion of mineral fertilization in the second cycle, reaching, respectively, the maximum value estimated of 87.9 and $96.2 \mathrm{~mm}$ with the proportions of 97 and $82 \%$, while in the first cycle there were no significant differences between the proportions (Figure 4A e B). 
Figure 4 - Means of the diameter (A) and length (B) of fruits per plant of the yellow passion fruit under mineral and organic (worm compost) fertilization in Entisols Quartzipsamment A
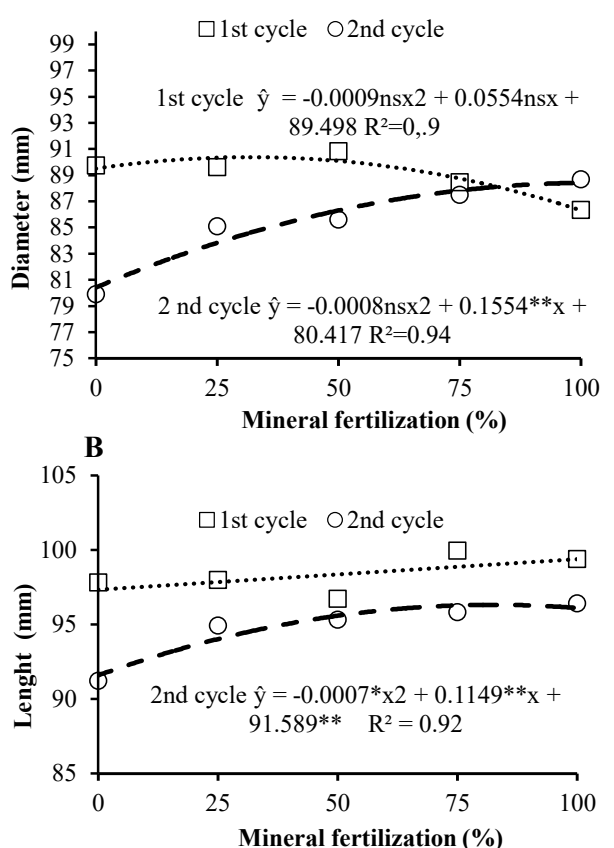

ns $=$ non-significant, $*$ and $* *$ significant at $5 \%$ and $1 \%$ respectively Source: survey data.

Cavalcante et al. (2016) using the same cultivar obtained values of 84.2 and $99.6 \mathrm{~mm}$, respectively, for the diameter and length. Just as occurred with the mass of fruits, the absence of response of chemical fertilization in the first cycle, to the diameters of the fruits, suggests that the worm compost applied during the first year of cultivation presented additional effect. The response that the chemical fertilization provoked in the growth of the fruits in the second cycle, probably due to the fact that the complementary fertilization was residual and showed no effect.

The relationship between the length and diameter of the fruits showed a quadratic decrease, with the minimum value estimated in the proportion of $40 \%$, with the first cycle and a linear decrease in the second cycle increasing the proportion of mineral fertilization (Figure 5).

Figure 5 - Means of the relationship between length and diameter of fruits per plant of the yellow passion fruit under mineral and organic (worm compost) fertilization in Entisols Quartzipsamments

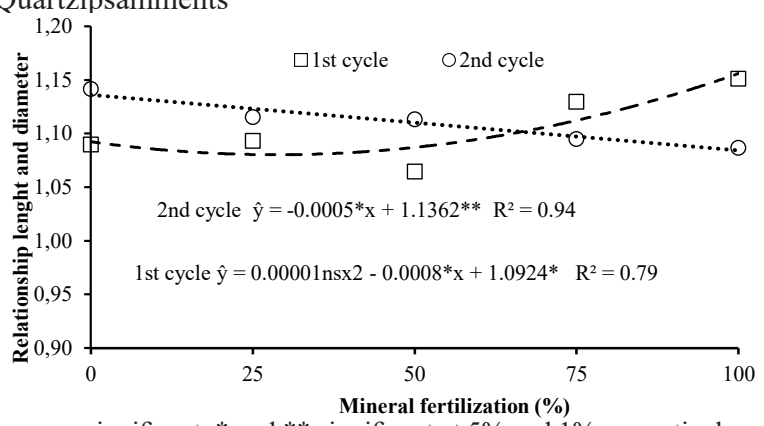

ns $=$ non-significant, $*$ and $* *$ significant at $5 \%$ and $1 \%$ respectively Source: survey data.
The higher the ratio among the diameters the more oval the fruit is, for this reason, it was visually observed that chemical fertilization turned the fruits less oval in the second cycle and in the first cycle until the proportion of 50\%. The highest values obtained for the first and second cycle, respectively, of 1.15 and 1.14, were equal to those obtained by Aguiar et al. (2017) and a little below the one obtained by Cavalcanti et al. (2016) of $1.18^{\circ}$ Brix (content of soluble solids) increased quadratically with the increase in the proportion of chemical fertilization, with the maximum value estimated in the proportion of $78.5 \%$ for the first cycle, and $91.2 \%$ for the second cycle (Figure 6).

Figure 6 - Means of the ${ }^{\circ}$ Brix of fruits per plant of the yellow passion fruit under mineral and organic (worm compost) fertilization in Entisols Quartzipsamments

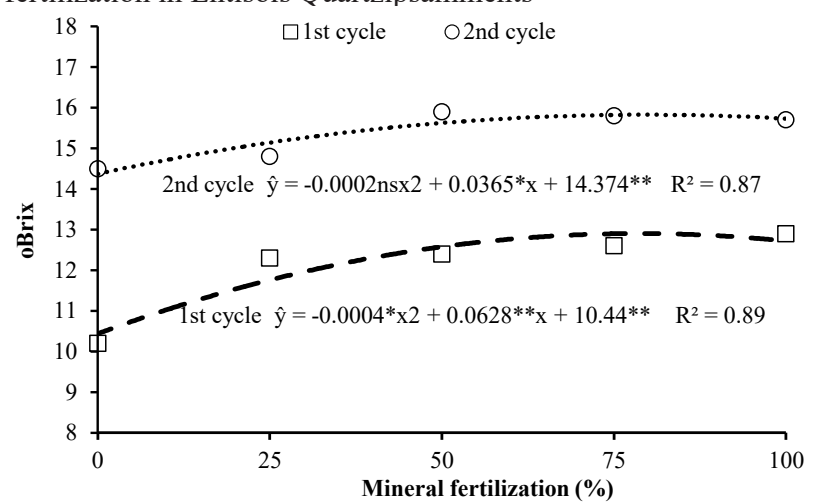

ns $=$ non-significant, $*$ and $* *$ significant at $5 \%$ and $1 \%$ respectively Source: survey data.

The effect of mineral fertilizer, is probably due to its largest supply of nutrients to the passion fruit. Nascimento et al. (2015) even using increasing doses of bio fertilizer, just found an increase in soluble solids content in the presence of the NPK fertilizer, something that was assigned to the adequate supply of nutrients to the plants subjected to this treatment, which influenced its physiology and its biochemical processes, resulting in higher formation of energy reserves, synthesis and translocation of photo assimilates to the fruits, increasing in the same the soluble solids content. The second cycle presented higher values than the first cycle, as well as recorded by Weber et al. (2016). The highest values obtained in this study of 12.9 and $15.9^{\circ}$ Brix, for the first and second cycle, respectively, are higher than those obtained by Cavalcante $e t$ al. (2016), $11.6^{\circ}$ Brix and Nascimento et al. (2015) of 12.78 ${ }^{\circ}$ Brix, and, considering the first cycle, below that obtained by Dias et al. (2011), $14.0^{\circ} \mathrm{Brix}$. It is desirable that the content of soluble solids is high. For industry, for example, the higher the value of this content in fruits, the lower the quantity of fruits used for the juice concentration (NEGREIROS et al., 2008).

\section{Conclusion}

The use of organic fertilizer only, without the mineral fertilization significantly reduces the productivity of yellow passion fruit. The mineral and organic fertilization does not 
affect the weight of yellow passiflora fruits. Only mineral fertilization can increase the total soluble solids content of passion fruit.

\section{References}

AGUIAR, Ana Verônica Menezes de;AGUIAR, A. V. M.2017AGUIAR, A.V.M. et al. Effect of biofertilization on yellow passion fruit production and fruit quality. Rev. Caatinga, v.30, n.1, p.136-148, 2017. doi: 10.1590/1983-21252017v30n115rc

ALMEIDA, R.F. Nutrição de maracujazeiro. Rev. Verde Agroecol. Desenvol. Sustentável, v.7, n.3, p.12-17, 2012.

ALVAREZ, V.H. et al. Interpretação dos resultados das análises de solos. In: RIBEIRO, A.C.; GUIMARÃES, P.T.G.; ALVAREZ, V.H. (Ed). Recomendações para o uso de corretivos e fertilizantes em Minas Gerais, $5^{a}$ Aproximação. Viçosa: Comissão de Fertilidade do Solo do Estado de Minas Gerais, 1999.

ARAÚJO, R.C. et al. Crescimento e produção do maracujazeiroamarelo em resposta à nutrição potássica. Rev. Bras. Fruticultura, v.27, n.1, p.128-131, 2005. doi: 10.1590/S010029452005000100034

AULAR, J. et al. Nutrição mineral e qualidade do fruto do abacaxizeiro e do maracujazeiro. Rev. Bras. Fruticultura, v.36, n.4, p.1046-1054, 2014. doi: 10.1590/0100-2945-269/14

CAMPOS, V.B. et al. Caracterização física e química de frutos de maracujazeiro amarelo sob adubação potássica, biofertilizante e cobertura morta. Rev. Bras. Prod. Agroindustrial, v.9, n.1, p.5971, 2007. doi: 10.15871/1517-8595/rbpa.v9n1p59-71

CAVALCANTE, N. R. et al. Productivity, fruit physicochemical quality and distinctiveness of passion fruit populations. Rev. Bras. Fruticultura, v.38, n.1, p.137-142, 2016. doi: 10.1590/010029452016142

DAVID, M. A. et al. Efeito de doses de superfosfato simples e de matéria orgânica sobre o crescimento de mudas de maracujazeiro amarelo. Pesq. Agrop. Trop., v.38, n.1, p.147-152. 2008.

DIAS, T.J. et al. Qualidade química de frutos do maracujazeiro amarelo em solo com biofertilizante irrigado com águas salinas. Rev. Bras. Eng. Agric. Amb., v.15, n.2, p.229-236, 2011. doi: $10.1590 / \mathrm{S} 1415-43662011000300002$

DONAGEMA, G. K. et al. (Org.). Manual de métodos de análise de solos. Rio de Janeiro: Embrapa Solos, 2011.

FORTALEZA, J.M. et al. Características físicas e químicas em nove genótipos de maracujá-azedo cultivado sob três níveis de adubação potássica. Rev. Bras Fruticultura, v.27, n.1, p.124-127, 2005. doi: 10.1590/S0100-29452005000100033

FREITAS, M.S.C.; ARAÚJO, C.A.S.; SILVA, D.J. Decomposição e liberação de nutrientes de estercos em função da profundidade e do tempo de incorporação. Rev. Sem. De Visu, v.2, n.1, p.150161, 2012.

KRAUSE, W. et al. Produtividade e qualidade de frutos de cultivares de maracujazeiro-amarelo com ou sem polinização artificial. Pesq. Agropec. Bras., v.47, n.12, p.1737-1742, 2012. doi: 10.1590/S0100-204X2012001200009

MELETTI, L.M.M. Avanços na cultura do maracujá no Brasil. Rev. Bras. Fruticultura, v.33, n.1, p.83-91, 2011. doi: 10.1590/

\section{S0100-29452011000500012}

MUELLER, S. et al. Produtividade de tomate sob adubação orgânica e complementação com adubos minerais. Horticultura Bras., v.31, n.1, p.86-92, 2013. doi: 10.1590/S010205362013000100014

NASCIMENTO, J.A.M. et al. Biofertilizante e adubação mineral na qualidade de frutos de maracujazeiro irrigado com água salina. Irriga, v.20, n.2, p.220-232, 2015. doi: 10.15809/ irriga. $2015 \mathrm{v} 20 \mathrm{n} 2 \mathrm{p} 200$

0.34NEGREIROS, J. R. da S.2008NEGREIROS, J.R.S. et al. Caracterização de frutos de progênies de meios-irmãos de maracujazeiro-amarelo em Rio Branco - Acre. Rev. Bras. Fruticultura, v.30, n.3, p.431-437, 2008. doi: 10.1590/S010029452008000200028

PACHECO, A.L. V. et al. Mineral composition of pulp and production of the yellow passion fruit with organic and conventional fertilizers. Food Chemistry, v.217, n.1, p.425-430, 2017. doi: 10.1016/J.FOODCHEM.2016.08.068

PIRES, A.A. et al. Efeito da adubação alternativa sobre os componentes de produção do maracujazeiro-amarelo. Acta Scie. Agro., v.3, n.4, p.655-660, 2009. doi: 10.4025/actasciagron. v31i4.986

RODOLFO JÚNIOR, F.; CAVALCANTE, L.F.; BURITI, E.S. Crescimento e produção do maracujazeiro amarelo em solo com biofertilizantes e adubação mineral com NPK. Rev. Caatinga, v.22, n.1, p.149-160. 2009.

SORRENTI, G.B. et al. Influência da adubação orgânica no crescimento de tangerineira cv Clemenules e nos atributos químicos e microbiológicos do solo. Rev. Bras. Fruticultura, v.30, n.7,p.1120-1135,2008. doi: 10.1590/S0100-29452008000400047

SOUSA, V.F. et al. Irrigação e fertirrigação do maracujazeiro. Teresina: Embrapa Meio-Norte, 2001.

SOUZA, H.R. et al. Use of organic compost containing waste from small ruminants in Corn Production. Rev. Bras. Ciênc. Solo, v.40, n.1, p.1-16, 2016. doi: 10.1590/18069657rbcs20150385

SOUZA, M. et al. Sugestões de adubação para diferentes culturas em Minas Gerais: Maracujazeiro. In: RIBEIRO, A.C.; GUIMARÃES, P.T.G.; ALVAREZ, V.V.H. (Ed). Recomendações para o uso de corretivos e fertilizantes em Minas Gerais, $5^{a}$ Aproximação. Viçosa: Comissão de Fertilidade do Solo do Estado de Minas Gerais, 1999.

TIECHER, T. et al. Respostas de culturas à adubação sulfatada $\mathrm{e}$ deposição de enxofre atmosférico. Rev. Ceres, v. 60, n.3, p.420427, 2013. doi: 10.1590/S0034-737X2013000300016

VALE, L.S.R. et al. Desempenho Agronômico de cultivares de maracujazeiro hibrido. Global Scie. Technol., v. 6, n. 3, p.178183, 2013. doi: 10.14688/1984-3801.v06n03a18

VASCONCELLOS, M.A.S. et al. Caracterização física e quantidade de nutrientes em frutos de maracujá doce. Rev. Bras. Fruticultura, v.23, n.4, p.690-694, 2001.doi: 10.1590/S010029452001000300049

WEBER, D. et al. Densidade de plantio e produção do maracujazeiro-azedo no sul do Brasil. Rev. Bras. Fruticultura, v.38, n.1, p.99-106, 2016. doi: 10.1590/0100-2945-283/14 